\title{
CYTOMORPHOLOGICAL CHARACTERISTIC EVALUATION OF THE THIRD GENERATION OF ARROWROOT PLANT (Maranta arundinacea L.) RADIATED BY GAMMA RAY
}

\section{EVALUASI KARAKTERISTIK CYTO-MORFOLOGI GENERASI KETIGA TANAMAN GARUT (Maranta arundinacea L.) HASIL RADIASI SINAR GAMMA}

\author{
Puspita Deswina ${ }^{* 1}$, Luluk Prihastuti ${ }^{2}$, Aziz Saputra ${ }^{2}$ \\ ${ }^{1}$ Bio-technology Research Centre, LIPI, Jl. Raya Bogor Km 46 Cibinong Science Center, 16911. \\ ${ }^{2}$ The Faculty of Agriculture, Universitas Nasional, Program Studi Agroteknologi. Jakarta \\ Korespondensi : pdeswina@gmail.com
}

Diterima: 11 Oktober 2019 / Disetujui: 25 November 2019

\begin{abstract}
Arrowroot plants (Maranta arundinacea L.) have enormous potential to be developed as the alternative foods. Various kinds of functional food products can be processed from arrowroot tubers, because they have lower calories and IG (Glycemic Index) contents compared to the other tubers. The study aimed to determine the characteristics of the phenotype, productivity and anatomy of leaves of arrowroot plants radiated by gamma ray. The study used factorial randomized block design with 2 factors. The first factor was arrowroot accessions (Pulosari, 25 Pandeglang, Cikondang, Tamansari, and MN-1), and the second factor was radiation dose $(0,10,20,30,40,50 \mathrm{Gray})$, and those was arranged in three replications. Based on the results of the study, it found that: Pulosari accession without radiation and 30 Gray radiation required the fastest time of 12 days for shoots growth. The highest plant growth $(106,88 \mathrm{~cm})$ was Cikondang accession with 20 Gray radiation treatment; while the shortest plant $(59.61 \mathrm{~cm})$ was found in Cikondang accession with 30 Gray radiation dose as well. The number of productive tillers (3.0) was mostly found in Pulosari accession without radiation, conversely, the least $(0.72)$ was found in $\mathrm{MN}-1$ accession with 20 Gray radiation. For the maximum number of out-of-section tillers (1.17) on the 25 Pandeglang accession with 40 Gray radiation. The longest leaf growth $(22.64 \mathrm{~cm})$ and the widest $(9.08 \mathrm{~cm})$ were found in Cikondang accession without radiation, conversely, the shortest leaf growth $(10.17 \mathrm{~cm})$ and smallest $(3.34 \mathrm{~cm})$ was found in Cikondang accession radiated by 40 Gray. There were no changes to the number and shape of the stomata between the control plants and the radiated treatment, but there were changes in leaf color on 25 Pandeglang accession with radiation treatment 40 Gray.
\end{abstract}

Key words: arrowroot, gamma radiation, alternative food, diversity

\section{ABSTRAK}

Tanaman Garut (Maranta arundinacea L.) memiliki potensi besar untuk dikembangkan sebagai pangan alternatif. Berbagai macam produk pangan fungsional dapat diolah dari umbi

Cite this as: Deswina, P., L. Prihastuti, dan A. Saputra. (2019). Cytomorphological characteristics evaluation of the third generation of arrowroot plant (Maranta arundinacea $\mathrm{L}$.) radiated by gamma ray. Jurnal Agro, 6(2), 181-195 https://doi.org/10.15575/6104 
Garut, karena memiliki kandungan IG (Index Glycemic) dan kalori lebih rendah dibandingkan umbiumbi lainnya. Penelitian ini bertujuan untuk mengetahui karakteristik fenotipe, produktivitas dan anatomi daun tanaman Garut yang diberi perlakuan radiasi sinar gamma. Penelitian disusun menggunakan Rancangan Acak Kelompok (RAK) Faktorial dengan 2 faktor, dengan faktor pertama aksesi tanaman (Pulosari, 25 Pandeglang, Cikondang, Tamansari, dan MN-1), dan faktor kedua adalah dosis radiasi $(0,10,20,30,40,50$ Gray), penelitian terdiri dari 3 ulangan. Berdasarkan hasil penelitian diketahui bahwa aksesi Pulosari tanpa radiasi dan radiasi 30 Gray memerlukan waktu keluar tunas paling cepat yaitu 12 hari. Pertumbuhan tanaman paling tinggi $(106,88 \mathrm{~cm})$ adalah aksesi Cikondang dengan perlakuan radiasi 20 Gray, sedangkan tanaman paling pendek $(59,61 \mathrm{~cm})$ juga terdapat pada aksesi Cikondang dengan dosis radiasi 30 Gray. Jumlah anakan produktif $(3,0)$ paling banyak terdapat pada aksesi Pulosari tanpa radiasi, sebaliknya yang paling sedikit $(0,72)$ terdapat pada aksesi MN-1 radiasi 20 Gray. Untuk jumlah anakan keluar ruas paling banyak $(1,17)$ pada aksesi 25 Pandeglang dengan dosis radiasi 40 Gray. Pertumbuhan daun paling panjang $(22,64$ $\mathrm{cm})$ dan paling lebar $(9,08 \mathrm{~cm})$ selama pengamatan terdapat pada aksesi Cikondang tanpa radiasi. Sebaliknya pertumbuhan daun paling pendek $(10,17 \mathrm{~cm})$ dan kecil $(3,34 \mathrm{~cm})$ juga terdapat pada aksesi Cikondang dan radiasi 40 Gray. Tidak terdapat perubahan terhadap jumlah dan bentuk stomata antara tanaman kontrol dengan perlakuan radiasi, akan tetapi terdapat perubahan warna daun pada aksesi 25 Pandeglang dengan perlakuan radiasi 40 Gray.

Kata Kunci: Garut, radiasi sinar gamma, pangan alternatif, keragaman 


\section{INTRODUCTION}

Arrowroot (Maranta arundinacea L.) is an alternative food source with high economic value and great potential to be developed as a raw material for developing functional-food products, especially for people with diabetes and digestive disorders. Arrowroot plants are herbaceous with a shallow root. Its bulbs are enlarged rhizomes in cylindrical forms; the leaves are elongated in oval-shape with the leaves blade encircling the trunk (Asha et al., 2015).

Arrowroot contains starch so it is potentially substitutes wheat flour (Hariyadi, 2010) or other common flours (Djaafar \& Rahayu, 2006). Arrowroot contains carbohydrates that can be used for food and industrial raw materials (Ramadhani et al., 2017) with highly nutritious; 25-30\% carbohydrate and $\pm 20 \%$ starch (Rahman et al., 2015). Arrowroot tuber offers health benefits because its glycemic index is as low as 14 , lower than flour, rice, potatoes, and cassava, which are around 100, 96, 90 and 54, respectively (Rahman et al., 2015). Arrowroot plants boost high economic value and can be found in all parts of Indonesia because its cultivation is relatively easy and does not require particular handling. By intensive cultivation these plants can produce an average of $21 \mathrm{t} \mathrm{ha}^{-1}$ (Sarjiman \& Djaafar, 2007).

Arrowroot is an introduced plant from Central America and South America that has adapted to the conditions in Indonesia. The plant can live on marginal or empty lands under a tree. Additionally, arrowroot cultivation have been done by farmers on non-irrigated or rainfed dry land. Arrowroot belongs to the family of Marantaceae, Maranta genus, Maranta arundinacea L. species, and is grouped to minor tubers. The local names of arrowroot are diverse, in West Java they are called patat sago, irut, arut, and jelarut; in Madura selarut or larut; in Gorontalo labia walanta; in Ternate huda sula, in Halmahera peda sula; and in America it's called Arrowroot (Djaafar et al., 2010). Arrowroot plants originated from America, specifically at the tropics, and then it spreads to other tropical countries (Shintu et al., 2016; Faridah et al., 2014).

The genetic diversity of arrowroot germplasm plays an important role in supporting the improvement of its own superior varieties, especially characters related to starch content and high yield (Sarjiman \& Djaafar, 2007). In the present, the opportunity to increase the genetic diversity of arrowroot through crossing is still difficult because its vegetative propagation and narrow number of arrowroot species. Induction mutation is an appropriate breeding method, especially for plants that has vegetative breeding (Soeranto, 2003). Induction of mutations with gamma rays is the best technique compared to chemical methods, because it can produce the most mutants (around $75 \%$ ). In addition, gamma rays are more accurate and the penetration of radiation into cells is homogeneous (Zanzibar \& Witjaksono, 2011).

The results showed that the dose of gamma ray radiation in the M4 generation was significantly different in germination time, seed germination energy, and plant height (Gurning et al., 2013). The results of Jan et al. (2011) research on some arrowroot plants from Malang, Bogor, and Bantul showed no significant differences in their morphological characters. The results of the analysis of the genetic diversity of 19 Indonesian arrowroot accessions carried out through molecular markers of RAPD have shown that they are not genetically different, thus the limited supply of superior arrowroot genotypes from existing germplasm is one of the limiting factors in 
arrowroot breeding programs (Deswina et al., 2019).

The objective of this study was to determine the cytomorphological characters of third generation arrowroot plants radiated by gamma ray. Induction mutations can cause genetic diversity, because genetic material changes at the level of the genome, chromosomes, and DNA or genes (Giono et al., 2014). Through mutation breeding a number of arrowroot mutants will be produced that are better than the original germplasm.

\section{MATERIALS AND METHODS}

This research was conducted on February 2018 - November 2018, at the Agronomy Lab and Germplasm Gardens (GG) LIPI Cibinong Science Center (CSC), Bogor Regency, West Java Province. The study was arranged by using Randomized Block Design (RBD) Factorial with three replications. Factor I consisted of 5 accessions of arrowroot plants (Table 1); Factor II was the dose of gamma irradiation consisting

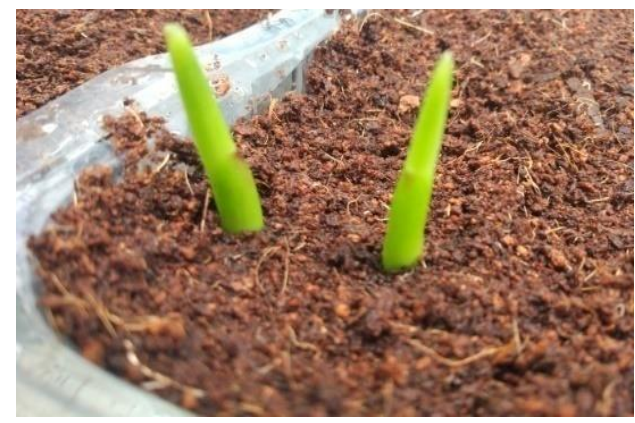

A of: 0 (control), 10 Gray, 20 Gray, 30 Gray, 40 Gray, and 50 Gray.

Table 1. Arrowroot Plant Collection at Germplasm Garden (GG) LIPI Cibinong Science Center, Bogor Regency, West Java Province

\begin{tabular}{lll}
\hline Code & Accessions & \multicolumn{1}{c}{ Origin } \\
\hline a1 & Pulosari & Jawa Barat \\
a2 & 25 Pandeglang & Jawa Barat \\
a3 & Cikondang & Jawa Barat \\
a4 & Tamansari & DI Yogyakarta \\
a5 & MN-1 & Jawa Barat \\
\hline
\end{tabular}

The second generation of arrowroot mutant $\left(M_{2} V_{1}\right)$ was germinated in the seedling media consist of coco peat, which dried by the sun. The germinated seed selected from the healthy ones; $2-5 \mathrm{~cm}$ in diameter, $4-7 \mathrm{~cm}$ in length, with 2-4 buds (Fig 1A). Bulbs were immersed approximately $1-2 \mathrm{~cm}$ into the seedling media. Observations were made until the buds appeared to surface (Figure 1B). The planting media used in the polybag; soil, manure, and husks mixed with a ratio of 2:1:1. The size of the polybag was $50 \mathrm{~cm} \times 50 \mathrm{~cm}$.

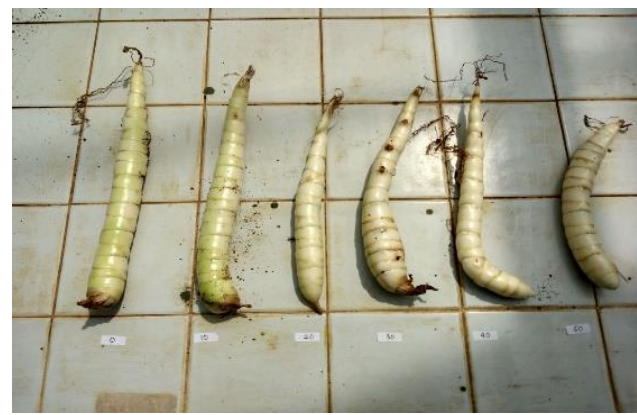

B

Figure 1. The second generation of arrowroot shoots (A) and tubers (B

Particularly, loose soil structure is preferable for tuber growth. Moreover, the harvesting process would also be easier and faster if the soil were loose. The shoots of arrowroot plants that germinated and measured to the $5 \mathrm{~cm}$ tall could be transferred to the planting media. Fertilizers was applied in the beginning of cultivation. Afterwards, in 3-4 months when the plant begin to bloom or when tubers were starting to emerge from 6-7 months. Weed control by removing weeds and maintaining adequate media in polybags so that the formation of 
tubers in the soil will be undisturbed. Weeding, pest and disease control can be adjusted according to needs.

\section{Morphological Observation}

Data collected includes qualitative and quantitative observations. The qualitative variables collected to complete the quantitative characters, such as leaf color, leaf mid-vein color and leaf vein color. The quantitative

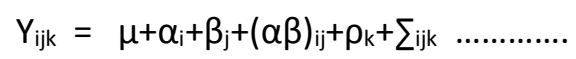

Note:
$Y_{\mathrm{ijk}}$
The value of observations on factor A level I factor $B$ level $j$ and kth group
$\left(\mu \alpha_{i} \beta_{j}\right)$
Additive components
influence of factor $B$.
$(\alpha \beta)_{\mathrm{ij}}$
$\rho_{\mathrm{k}}$ Component of interaction of factor A and factor B.
$\sum_{\mathrm{ijk}}$

characters variables being observed were; plant height, leaf length and leaf width, number of tillers and number of tillers per clump.

The data were tested using correlation between quantitative characters, analysis of variance followed by Duncan's multiple range test at the 5\% level (Gomez and Gomez 1995). Linier model are showed in equation (1):

\section{Observation of Anatomical Stomata}

The leaves of the arrowroot plant were cut, put the stem into a bottle of water, clean the surface of the leaf with $70 \%$ alcohol, attach 2.5 $\mathrm{cm}$ of scotch tape on the leaf by applying a sufficient pressure, coat the leaf with nail polish thoroughly, leave it to dry ( \pm 1 hour). Apply 1.2 $\mathrm{cm}$ of scotch tape on the surface of the leaf coated with nail polish, remove the attached nail polish and put it on the preparation glass. The stomata preparation can then be observed under a microscope. Calculate stomata density and damage percentage with the following formula:

Stomata Density $=\frac{\text { The number of stomata }}{\text { Field of View Area }}$

Where, broad field of view for enlargement 400 $x=1 / 4 \pi d 2=1 / 4 \times 3,14 \times(0,5) 2=0,19625 \mathrm{~mm}^{2}$. Measuring the leaf width of each experimental unit, 3 leaves were chosen to represent each treatment. While stomata damage can be calculated with the following formula, adopted from Lestari (2006):

$\frac{\text { The amount of damaged Stomata }}{\text { The amount of Stomata being observed }} \times 100 \%$

\section{RESULTS AND DISCUSSION}

\section{Morphological Characteristics}

\section{Growth of the Shoots}

Based on the observations of shoots growth, Pulosari accession with the control treatment $(\mathrm{a} 1 \mathrm{e} 0)$ and $\mathrm{a} 1 \mathrm{r} 3$ have shown better shoot growth compared to other treatments, it took only \pm 12 days for it to grow. While for Cikondang accession a3r3 and a3r4 treatment would take the longest shoots growth of about \pm 47 days. Tubers administered with high doses of irradiation (40 and 50 Gray) have much slower growth rate compared to the others (Table 2). The factors were suspected from external factors. Hidayat et al. (2012) stated that the growth of bitter plants became slower due to the irradiation treatment. According to Yuniastuti (2012), arrowroot seeds must go 
through a shelf life to break dormancy before being used for subsequent planting. Lathifah et al. (2017) stated that tubers that are ready for planting are tubers that have germinated around $2 \mathrm{~cm}$. Tubers that have not germinated or are in a period of dormancy are not suitable to be planted because the growth is slower, sometimes they would rot underneath the soil and the tuber yield is very poor. Data on the length of shoot growth showed in Table 2.

Table 2. The combination of accession and radiation treatment on the time of shoot release.

\begin{tabular}{cccccc}
\hline Treatment & $\begin{array}{c}\text { Duration } \\
\text { (Days) }\end{array}$ & Notes & Treatment & $\begin{array}{c}\text { Duration } \\
\text { (Days) }\end{array}$ & Notes \\
\hline a1r0 & 12 & - & a3r3 & 47 & - \\
a1r1 & 21 & - & $a 3 r 4$ & 47 & - \\
a1r2 & 21 & - & $a 3 r 5$ & 35 & - \\
a1r3 & 12 & - & $a 4 r 0$ & 35 & Embroidered \\
a1r4 & 32 & - & $a 4 r 1$ & 32 & - \\
a1r5 & 21 & - & $a 4 r 2$ & 35 & - \\
a2r0 & 21 & - & $a 4 r 3$ & 21 & - \\
a2r1 & 21 & - & $a 4 r 4$ & 35 & - \\
a2r2 & 21 & - & $a 4 r 5$ & 32 & - \\
a2r3 & 35 & - & $a 5 r 0$ & 45 & Embroidered \\
a2r4 & 32 & - & $a 5 r 1$ & 21 & - \\
a2r5 & 35 & - & $a 5 r 2$ & 35 & - \\
a3r0 & 14 & - & $a 5 r 3$ & 35 & Embroidered \\
a3r1 & 32 & - & $a 5 r 4$ & 32 & Embroidered \\
a3r2 & 32 & - & $a 5 r 5$ & 32 & Embroidered \\
\hline
\end{tabular}

Note: A1 (Pulosari), A2 (25 Pandeglang), A3 (Cikondang), A4 (Tamansari), dan A5 (MN-1). RO (kontrol), $R 1$ (10 Gy), R2 (20 Gy), R3 (30 Gy), R4 (40 Gy), dan R5 (50 Gy).

\section{Plant Height}

The plant heights were observed in 4, 5, and 6 months after planting (MAP). Plant height is a growth indicator or a parameter to determine the effect of the environment on treatment. Plant height is the most observable measure of growth (Gusmaini et al., 2003). The results of analysis of variance have shown that the accession, radiation, and interactions factors had a significant effect on plant height at 4, 5 and 6 MAP.

Table 3. Interaction between accessions and radiation doses on the height of arrowroot plants aged 4, 5, 6 months after planting.

\begin{tabular}{clll}
\hline Interactions & \multicolumn{3}{c}{ Average $(\mathrm{cm})$} \\
\cline { 2 - 4 } & Month 4 & Month 5 & Month 6 \\
\hline a1r0 & $57.08 \mathrm{~cd}$ & $74.48 \mathrm{~cd}$ & $88.91 \mathrm{~cd}$ \\
a1r1 & $59.72 \mathrm{~cd}$ & $78.19 \mathrm{~d}$ & $96.94 \mathrm{~d}$ \\
a1r2 & $61.57 \mathrm{~d}$ & $87.07 \mathrm{de}$ & $89.68 \mathrm{~cd}$ \\
a1r3 & $66.29 \mathrm{~d}$ & $90.33 \mathrm{e}$ & $99.38 \mathrm{~d}$ \\
a1r4 & $45.40 \mathrm{bc}$ & $55.49 \mathrm{~b}$ & $73.06 \mathrm{~b}$ \\
a1r5 & $66.70 \mathrm{~d}$ & $88.32 \mathrm{de}$ & $103.78 \mathrm{~d}$ \\
a2r0 & $64.91 \mathrm{~d}$ & $92.38 \mathrm{e}$ & $100.25 \mathrm{~d}$ \\
a2r1 & $63.49 \mathrm{~d}$ & $80.53 \mathrm{de}$ & $96.18 \mathrm{~cd}$ \\
a2r2 & $57.79 \mathrm{~cd}$ & $86.03 \mathrm{de}$ & $102.50 \mathrm{~d}$
\end{tabular}




\begin{tabular}{cccc}
\hline Interactions & \multicolumn{3}{c}{ Average $(\mathrm{cm})$} \\
\cline { 2 - 4 } & Month 4 & Month 5 & Month 6 \\
\hline a2r3 & $56.68 \mathrm{~cd}$ & $76.87 \mathrm{~cd}$ & $101.58 \mathrm{~d}$ \\
a2r4 & $56.43 \mathrm{~cd}$ & $72.73 \mathrm{~cd}$ & $85.88 \mathrm{c}$ \\
a2r5 & $51.14 \mathrm{~cd}$ & $79.48 \mathrm{de}$ & $89.15 \mathrm{~cd}$ \\
a3r0 & $67.87 \mathrm{~d}$ & $86.91 \mathrm{de}$ & $96.63 \mathrm{~d}$ \\
a3r1 & $54.40 \mathrm{~cd}$ & $83.55 \mathrm{de}$ & $97.31 \mathrm{~d}$ \\
a3r2 & $65.81 \mathrm{~d}$ & $92.93 \mathrm{e}$ & $106.88 \mathrm{~d}$ \\
a3r3 & $39.87 \mathrm{bc}$ & $67.41 \mathrm{a}$ & $88.29 \mathrm{~cd}$ \\
a3r4 & $20.43 \mathrm{a}$ & $41.01 \mathrm{a}$ & $59.61 \mathrm{a}$ \\
a3r5 & $43.02 \mathrm{bc}$ & $69.23 \mathrm{~cd}$ & $82.00 \mathrm{bc}$ \\
a4r0 & $58.38 \mathrm{~cd}$ & $82.89 \mathrm{de}$ & $100.82 \mathrm{~d}$ \\
a4r1 & $62.08 \mathrm{~d}$ & $77.25 \mathrm{~cd}$ & $93.48 \mathrm{~cd}$ \\
a4r2 & $49.15 \mathrm{~cd}$ & $73.20 \mathrm{~cd}$ & $92.92 \mathrm{~cd}$ \\
a4r3 & $66.84 \mathrm{~d}$ & $88.81 \mathrm{e}$ & $102.39 \mathrm{~d}$ \\
a4r4 & $39.45 \mathrm{bc}$ & $62.83 \mathrm{bc}$ & $82.28 \mathrm{bc}$ \\
a4r5 & $51.78 \mathrm{~cd}$ & $81.48 \mathrm{de}$ & $95.36 \mathrm{~cd}$ \\
a5r0 & $44.48 \mathrm{bc}$ & $69.73 \mathrm{~cd}$ & $88.80 \mathrm{~cd}$ \\
a5r1 & $55.84 \mathrm{~cd}$ & $83.30 \mathrm{de}$ & $88.58 \mathrm{~cd}$ \\
a5r2 & $34.21 \mathrm{~b}$ & $63.77 \mathrm{bc}$ & $81.99 \mathrm{bc}$ \\
a5r3 & $35.74 \mathrm{bc}$ & $65.10 \mathrm{bc}$ & $89.13 \mathrm{~cd}$ \\
a5r4 & $43.78 \mathrm{bc}$ & $61.28 \mathrm{bc}$ & $83.11 \mathrm{bc}$ \\
a5r5 & $48.01 \mathrm{c}$ & $75.20 \mathrm{~cd}$ & $91.31 \mathrm{~cd}$ \\
\hline
\end{tabular}

Note: The numbers followed by the same letters are not significantly different at the $5 \%$ level according to the Duncan test.

From Table 3, it was found that the interaction between accessions and radiation doses at 6 MAP of the a3r2 treatment provided the highest results $(106.88 \mathrm{~cm})$, while the A3R4 treatment produced the shortest plant height $(59.61 \mathrm{~cm})$. a1r0 treatment (control) was not significantly different from a1r2 but was significant from a1r1, a1r3, a1r4 and a1r5. a2ro treatment was not significantly different from $\mathrm{a} 2 \mathrm{r} 1, \mathrm{a} 2 \mathrm{r} 2$, and $\mathrm{a} 2 \mathrm{r} 3$ but was significantly different from a2r4 and a2r5. The a3r0 treatment was not significantly different from the a3r1, a3r2, and a3r3 but was significantly different from the a3r4 and a3r5 treatments. The A4RO treatment was not significantly different from a $4 \mathrm{r3}$ but was significantly different from a4r1, a4r2, a4r4, and a4r5. The a5r0 treatment was not significantly different from a5r1, a5r3, and a5r5 but have shown a significant difference from $\mathrm{a} 5 \mathrm{r} 2$, and $\mathrm{a} 5 \mathrm{r} 4$. According to Oktafani (2018), plant height is influenced by internal and external factors. Based on the results of analysis of variance there is a link between internal (accession) and external (radiation treatment) factors, where external factors have a very significant effect compared to internal factors. In the induction of chrysanthemum (Chrysanthemum morifolium) mutations with a radiation dose of 10-40 Gray, plant height results tend to be lower than the control plants (Yamaguchi et al., 2008).

Each plant has own tolerance that is different from growth environment including to sunlight. Some plants grow well in the open area and some grow well with low light intensity or in the shade. Arrowroot is a low light adaptive plant, under the light intensity 7400 lux (27\% full light), the number of leaves and tillers were not different under full light, while the plant is higher (Kusmiyati, 2013). According to Suhartini \& Hadiatmi (2011), arrowroot plants are plants that would grow 
optimally under tree stands with minimum light intensity. The results of further tests on the effect of accession on plant height presented in Table 4.

Table 4. Effect of arrowroot accession and radiation on plant height aged 4, 5 and 6 MAP.

\begin{tabular}{lccc}
\hline Accessions & \multicolumn{3}{c}{ Average (cm) } \\
\cline { 2 - 4 } & Month 4 & Month 5 & Month 6 \\
\hline a1 (Pulosari) & $59.46 \mathrm{~b}$ & $78.98 \mathrm{c}$ & $91.96 \mathrm{~b}$ \\
a2 (25 Pandeglang) & $58.41 \mathrm{~b}$ & $81.33 \mathrm{c}$ & $95.92 \mathrm{~b}$ \\
a3 (Cikondang) & $48.56 \mathrm{a}$ & $73.50 \mathrm{ab}$ & $88.45 \mathrm{ab}$ \\
a4 (Tamansari) & $54.61 \mathrm{~b}$ & $77.74 \mathrm{bc}$ & $94.54 \mathrm{~b}$ \\
a5 (MN-1) & $43.68 \mathrm{a}$ & $69.73 \mathrm{a}$ & $87.15 \mathrm{a}$ \\
\hline Radiation doses & & & \\
\hline r0 (control) & $58.54 \mathrm{~cd}$ & $81.28 \mathrm{~b}$ & $95.08 \mathrm{~b}$ \\
r1 (10 Gray) & $59.10 \mathrm{~d}$ & $80.56 \mathrm{~b}$ & $94.49 \mathrm{~b}$ \\
r2 (20 Gray) & $53.70 \mathrm{bc}$ & $80.59 \mathrm{~b}$ & $94.79 \mathrm{~b}$ \\
r3 (30 Gray) & $53.08 \mathrm{bc}$ & $77.70 \mathrm{~b}$ & $96.15 \mathrm{~b}$ \\
r4 (40 Gray) & $41.10 \mathrm{a}$ & $58.67 \mathrm{a}$ & $76.78 \mathrm{a}$ \\
r5 (50 Gray) & $52.13 \mathrm{~b}$ & $78.74 \mathrm{~b}$ & $92.32 \mathrm{~b}$
\end{tabular}

Note: The numbers followed by the same letters are not significantly different at the $5 \%$ level according to the Duncan test

Based on the results in Table 4, it was found that accession of 25 Pandeglang (a2) revealed the maximum height $(95.92 \mathrm{~cm})$ in observations of $6 \mathrm{MAP}$, while the shortest was accession of $\mathrm{MN}-1(87.15 \mathrm{~cm})$. MN-1 accession was significantly different from Pulosari accession, 25 Pandeglang, Cikondang, and Tamansari.

The effect of radiation doses on plant height showed that the control treatment (r0) was not significantly different from the treatment of radiation doses of $10,20,30$, and 50 Gray, but show significant differences with the treatment of 40 Gray and 50 Gray. Treatment of 30 Gray radiation dose showed the highest plant height $(96.15 \mathrm{~cm})$ at 6 BST observations, while 40 Gray radiation treatment showed the lowest plant height $(76.78 \mathrm{~cm})$. Induction of mutations with radiation can cause damage and abnormalities in plant physiology, morphology, and cytology (Kaurr et al., 2017).

Table 5. Interaction between accessions and radiation doses on the number of productive tillers and tillers out of sections.

\begin{tabular}{ccc}
\hline Interactions & Productive Tillers & Tillers out of Section \\
\hline a1r0 & $3.00 \mathrm{a}$ & $0.94 \mathrm{~b}$ \\
$\mathrm{a} 1 \mathrm{r} 1$ & $2.39 \mathrm{~b}$ & $0.78 \mathrm{bc}$ \\
$\mathrm{a} 1 \mathrm{r} 2$ & $1.28 \mathrm{c}$ & $0.78 \mathrm{bc}$ \\
$\mathrm{a} 1 \mathrm{r} 3$ & $2.94 \mathrm{a}$ & $0.61 \mathrm{c}$ \\
$\mathrm{a} 1 \mathrm{r} 4$ & $2.72 \mathrm{ab}$ & $1.06 \mathrm{ab}$ \\
$\mathrm{a} 1 \mathrm{r} 5$ & $2.44 \mathrm{ab}$ & $0.89 \mathrm{~b}$ \\
$\mathrm{a} 2 \mathrm{r} 0$ & $1.83 \mathrm{bc}$ & $0.78 \mathrm{bc}$ \\
$\mathrm{a} 2 \mathrm{r} 1$ & $2.33 \mathrm{~b}$ & $1.06 \mathrm{ab}$ \\
\hline
\end{tabular}




\begin{tabular}{lll}
\hline $\mathrm{a} 2 \mathrm{r} 2$ & $2.94 \mathrm{a}$ & $0.61 \mathrm{c}$ \\
$\mathrm{a} 2 \mathrm{r} 3$ & $2.22 \mathrm{~b}$ & $0.89 \mathrm{~b}$ \\
$\mathrm{a} 2 \mathrm{r} 4$ & $2.11 \mathrm{bc}$ & $1.17 \mathrm{a}$ \\
$\mathrm{a} 2 \mathrm{r} 5$ & $1.56 \mathrm{bc}$ & $0.56 \mathrm{c}$ \\
$\mathrm{a} 3 \mathrm{r} 0$ & $2.33 \mathrm{~b}$ & $0.56 \mathrm{c}$ \\
$\mathrm{a} 3 \mathrm{r} 1$ & $1.72 \mathrm{bc}$ & $0.78 \mathrm{bc}$ \\
$\mathrm{a} 3 \mathrm{r} 2$ & $2.06 \mathrm{bc}$ & $0.94 \mathrm{~b}$ \\
$\mathrm{a} 3 \mathrm{r} 3$ & $1.11 \mathrm{c}$ & $0.28 \mathrm{c}$ \\
$\mathrm{a} 3 \mathrm{r} 4$ & $1.06 \mathrm{c}$ & $0.00 \mathrm{c}$ \\
$\mathrm{a} 3 \mathrm{r} 5$ & $1.61 \mathrm{bc}$ & $0.28 \mathrm{c}$ \\
$\mathrm{a} 4 \mathrm{r} 0$ & $1.67 \mathrm{bc}$ & $0.39 \mathrm{c}$ \\
$\mathrm{a} 4 \mathrm{r} 1$ & $1.89 \mathrm{bc}$ & $0.83 \mathrm{bc}$ \\
$\mathrm{a} 4 \mathrm{r} 2$ & $1.50 \mathrm{c}$ & $0.39 \mathrm{c}$ \\
$\mathrm{a} 4 \mathrm{r} 3$ & $2.22 \mathrm{~b}$ & $1.06 \mathrm{ab}$ \\
$\mathrm{a} 4 \mathrm{r} 4$ & $1.06 \mathrm{c}$ & $0.28 \mathrm{c}$ \\
$\mathrm{a} 4 \mathrm{r} 5$ & $1.50 \mathrm{c}$ & $0.44 \mathrm{c}$ \\
$\mathrm{a} 5 \mathrm{r} 0$ & $1.50 \mathrm{c}$ & $0.28 \mathrm{c}$ \\
$\mathrm{a} 5 \mathrm{r} 1$ & $1.67 \mathrm{bc}$ & $0.22 \mathrm{c}$ \\
$\mathrm{a} 5 \mathrm{r} 2$ & $0.72 \mathrm{c}$ & $0.22 \mathrm{c}$ \\
$\mathrm{a} 5 \mathrm{r} 3$ & $1.00 \mathrm{c}$ & $0.11 \mathrm{c}$ \\
$\mathrm{a} 5 \mathrm{r} 4$ & $2.06 \mathrm{bc}$ & $0.56 \mathrm{bc}$ \\
$\mathrm{a} 5 \mathrm{r} 5$ & $1.61 \mathrm{bc}$ & $0.44 \mathrm{c}$ \\
\hline
\end{tabular}

Note: The numbers followed by the same letters are not significantly different at the 5\% level according to the Duncan test.

\section{The number of productive tillers and tillers out the section}

The observations of the number of productive tillers and tillers out of section were carried out when arrowroot plants at 2 - 6 months after planting. The average number of productive tillers and the number of tillers out of section of arrowroot plant in certain accessions presented in Table 5.

From the results showed that the interaction of accessions and radiation doses in the A1R0 treatment gave the most productive number of tillers (3.00) and different from all other treatments (Table 5). While the a5r2 treatment produced number of productive tillers of at least 0.72 . The results of the analysis of variance on the number of outgoing tillers were found that the interactions between accessions and radiation doses on the a2r4 treatment showed the most number of outgoing tillers (1.17). Whereas the a3r4 treatment did not obtain the number of tillers coming out of the segment. This is presumably because the arrowroot rhizome used as planting material is an intact rhizome without cutting the tuber into several parts that may lead to producing new shoots.

Table 6. Interaction between accessions and radiation doses on the average length and width of leaves of arrowroot plants.

\begin{tabular}{|c|c|c|c|}
\hline Interactions & $\begin{array}{l}\text { Leaf 's Average Length } \\
(\mathrm{cm})\end{array}$ & $\begin{array}{l}\text { Leaf's Average Width } \\
(\mathrm{cm})\end{array}$ & Notes \\
\hline a1ro & $14,58 \mathrm{bc}$ & $5,78 b c$ & \\
\hline a1r1 & $19,88 c$ & $7,29 b c$ & \\
\hline $\mathrm{a} 1 \mathrm{r} 2$ & $19,23 c$ & $7,71 \mathrm{c}$ & \\
\hline a1r3 & $20,02 c$ & $7,70 \mathrm{c}$ & \\
\hline
\end{tabular}




\begin{tabular}{|c|c|c|c|}
\hline Interactions & $\begin{array}{l}\text { Leaf 's Average Length } \\
\qquad(\mathrm{cm})\end{array}$ & $\begin{array}{l}\text { Leaf's Average Width } \\
(\mathrm{cm})\end{array}$ & Notes \\
\hline a1r4 & $18,43 \mathrm{bc}$ & $7,33 \mathrm{bc}$ & \\
\hline a1r5 & $21,61 c$ & $8,39 \mathrm{~cd}$ & \\
\hline $\mathrm{a} 2 \mathrm{r} 0$ & $17,55 b c$ & $6,49 b c$ & \\
\hline $\mathrm{a} 2 \mathrm{r} 1$ & $19,36 c$ & $7,84 c$ & \\
\hline $\mathrm{a} 2 \mathrm{r} 2$ & $15,18 b c$ & $6,13 b c$ & \\
\hline$a 2 r 3$ & $16,82 \mathrm{bc}$ & $6,76 b c$ & \\
\hline $\mathrm{a} 2 \mathrm{r} 4$ & $16,45 b c$ & $6,98 b c$ & \\
\hline $\mathrm{a} 2 \mathrm{r} 5$ & $12,82 \mathrm{ab}$ & $5,37 b$ & \\
\hline a3ro & $22,64 c$ & $10,17 d$ & \\
\hline a3r1 & $16,67 \mathrm{bc}$ & $6,99 b c$ & \\
\hline$a 3 r 2$ & $19,83 c$ & $8,09 c$ & \\
\hline a3r3 & $13,79 a b$ & $5,51 b c$ & \\
\hline a3r4 & $9,08 a$ & $3,34 a$ & \\
\hline a3r5 & $12,63 a b$ & $5,40 b$ & \\
\hline $\mathrm{a} 4 \mathrm{r} 0$ & $17,33 b c$ & $7,21 b c$ & \\
\hline a4r1 & $19,39 c$ & $7,43 c$ & \\
\hline $\mathrm{a} 4 \mathrm{r} 2$ & $15,01 b c$ & $6,53 b c$ & \\
\hline $\mathrm{a} 4 \mathrm{r} 3$ & $17,87 \mathrm{bc}$ & $6,91 b c$ & \\
\hline a 4 r4 & $11,77 a b$ & $5,01 a b$ & \\
\hline $\mathrm{a} 4 \mathrm{r} 5$ & $14,07 \mathrm{~b}$ & $6,01 b c$ & \\
\hline a5ro & $12.96 \mathrm{ab}$ & $4.90 \mathrm{ab}$ & \\
\hline$a 5 r 1$ & $15.22 \mathrm{bc}$ & $6.20 \mathrm{bc}$ & \\
\hline$a 5 r 2$ & $11.32 \mathrm{ab}$ & $4.97 a b$ & \\
\hline$a 5 r 3$ & $11.32 \mathrm{ab}$ & $4.93 a b$ & \\
\hline$a 5 r 4$ & $15.36 \mathrm{bc}$ & $6.27 b c$ & \\
\hline a5r5 & $17.37 \mathrm{bc}$ & $6.57 \mathrm{bc}$ & \\
\hline
\end{tabular}

Note: The numbers followed by the same letters are not significantly different at the 5\% level according to the Duncan test.

Dewanti (2004) and Arifin et al. (2014) explained that the difference in cuttings of the base, middle, and the end rhizome that will be used as planting material will affect plant growth and development.

\section{Leaf Length and Width}

The average length and width of the leaf measured from the 3rd youngest leaf at the top, the leaves' position can be erect or droop or anything in between. Length measurements are carried out from the base of the leaf (on the leaf stem) to the tip of the leaf. The width of the leaf is measured in the middle of the leaf. From the results of observations on the average length and width of the leaves obtained results as presented (Table 6 ).

From Table 6 can be observed that the interaction between accessions and radiation doses in the a3r0 treatment yield the longest $(22.64 \mathrm{~cm})$ and the widest $(10.17 \mathrm{~cm})$ leaves. While the a3r4 treatment gave the shortest $(9.08 \mathrm{~cm})$ and the smallest $(3.34 \mathrm{~cm})$ leaves. The a1r0 treatment (Control) was not significantly different from a1r4 but was significantly different from a1r1, a1r2, a1r3 and a1r5. Glover (2007) stated that the treatment of various doses of gamma irradiation in carnation plants did not cause differences in the vegetative characters of the several genotypes tested, 
including plant height, leaf number, leaf length, and leaf width.

Based on Table 7, Pulosari (a1) accession has the most length and width of leaves, which are $18.9 \mathrm{~cm}$ and $7.37 \mathrm{~cm}$, compared to the accessions of 25 Pandeglang (a2), Cikondang (a3), Tamansari (a4), and $\mathrm{MN}-1$ (a5). On the other hand, the shortest length and width of leaves was found in $\mathrm{MN}-1$ (a5) accession, which are $13.92 \mathrm{~cm}$ and $5.64 \mathrm{~cm}$.

Table 7. Effect of accessions and radiation doses on the average leaves length and width.

\begin{tabular}{lcc}
\hline Accessions & $\begin{array}{c}\text { Leaves' Average Length } \\
\text { (cm) }\end{array}$ & $\begin{array}{c}\text { Leaves' Average Width } \\
\text { (cm) }\end{array}$ \\
\hline a1 (Pulosari) & $18.96 \mathrm{c}$ & $7.37 \mathrm{c}$ \\
a2 (25 Pandeglang) & $16.37 \mathrm{~b}$ & $6.59 \mathrm{~b}$ \\
a3 (Cikondang) & $15.78 \mathrm{ab}$ & $6.58 \mathrm{~b}$ \\
a4 (Tamansari) & $15.91 \mathrm{~b}$ & $6.52 \mathrm{~b}$ \\
a5 (MN-1) & $13.92 \mathrm{a}$ & $5.64 \mathrm{a}$ \\
\hline Radiation Doses & & \\
\hline r0 (control) & $17.01 \mathrm{~b}$ & $6.91 \mathrm{~b}$ \\
r1 (10 Gy) & $18.10 \mathrm{~b}$ & $7.15 \mathrm{~b}$ \\
r2 (20 Gy) & $16.11 \mathrm{a}$ & $6.69 \mathrm{~b}$ \\
r3 (30 Gy) & $15.97 \mathrm{a}$ & $6.36 \mathrm{ab}$ \\
r4 (40 Gy) & $14.22 \mathrm{a}$ & $5.79 \mathrm{a}$ \\
r5 (50 Gy) & $15.70 \mathrm{a}$ & $6.35 \mathrm{ab}$
\end{tabular}

Note: The numbers followed by the same letters are not significantly different at the 5\% level according to the Duncan test.

According to Cahyuningdari (2002) and Anggun et al. (2018) by increasing number and size of leaves, plants are able to carry out photosynthesis to the maximum to support the transition process towards the reproductive phase. The results of further tests analysis in Table 7 showed that the average leaf length in the control treatment (RO) was not significantly different from the 10 Gray radiation treatment but it was significantly different with radiation treatment of 20 Gray, 30 Gray, 40 Gray, and 50 Gray. The treatment of 10 Gray radiation showed the highest leaf length and width of $18.10 \mathrm{~cm}$ and $7.15 \mathrm{~cm}$, while the 40 Gray radiation treatment gave the lowest leaf length and width results of $14.22 \mathrm{~cm}$ and $5.79 \mathrm{~cm}$. Maghfoer et al. (2003) stated that there is a relationship between leaf area and water availability whereas increasing leaf area would also increase the availability of water. The leaf area is also influenced by genetic factors, the number of leaves and its sizes. Reduced size of plant leaves such as their lengths and widths caused by radiation treatment will reduce the auxin content as far as interfering with auxin synthesis.

\section{Cyto-Morphology Stomata Analysis}

The number of stomata was calculated at the end of the observation and was carried out during the day. The leaves (samples) used were the first, the second, and the third leaves which were calculated based on the first leaves that had been fully bloomed on the parent plant. Observations were done using the aid of Nikon light microscope at $10 x$ and $40 x$ magnification, with a field of view of $0.08 \mathrm{~mm}^{2}$, which could be seen in Figure 4. 


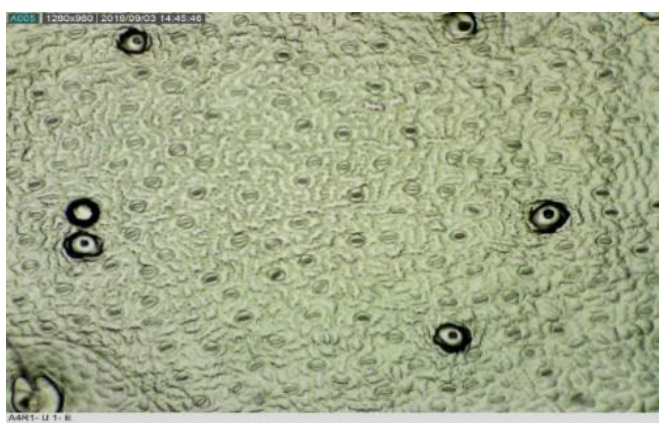

A

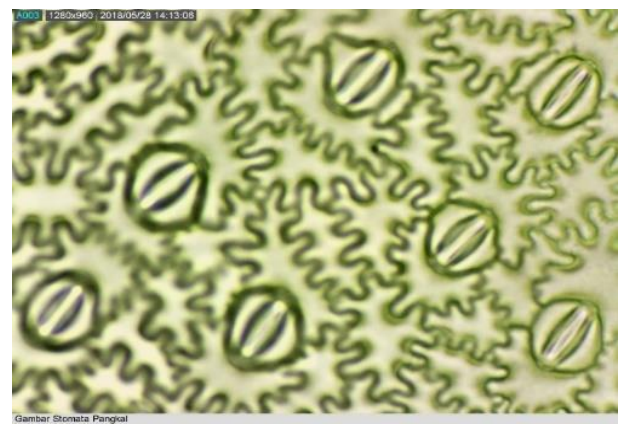

B

Figure 4: Arrowroot plant stomata at 10x (A) and 40x (B) magnification

Stomata of arrowroot plants is categorized as a diasitic type, where each closing cell is surrounded by two neighboring cells where the dividing wall is perpendicular to the stoma (Kaur et al., 2017). The stomata sampled from the bottom of the leaf because the number of stomata on the lower surface of the leaf is greater than the upper surface. As Kaur et al. (2017) stated, out of 100 plant species observed, almost all of the monocot and dicot plants that grow on land generally have stomata at the bottom of the leaf surface.
Based on the results presented in Table 8 below, it showed that the interaction between accession and radiation for the $\mathrm{a} 5 \mathrm{r} 2$ treatment has the least number of stomata which is 81.67 . The overall the data have shown that the number of stomata in accession $\mathrm{MN}-1$ (a5) has a fewer number stomata or significantly different from other plant species observed. Almost all of the monocot and dicot plants that grow on land generally have stomata at the bottom of the leaf surface (Sastra 2003., and Mutaqin et al., 2016).

Table 8. Effect of accession interactions and radiation doses on the number of leaves of the arrowroot plant stomata

\begin{tabular}{cl}
\hline Interaction Influence & Average \\
\hline $\mathrm{a} 1 \mathrm{r} 0$ & $140.33 \mathrm{~b}$ \\
$\mathrm{a} 1 \mathrm{r} 1$ & $124.00 \mathrm{c}$ \\
$\mathrm{a} 1 \mathrm{r} 2$ & $134.33 \mathrm{bc}$ \\
$\mathrm{a} 1 \mathrm{r} 3$ & $144.67 \mathrm{~b}$ \\
$\mathrm{a} 1 \mathrm{r} 4$ & $117.33 \mathrm{~cd}$ \\
$\mathrm{a} 1 \mathrm{r} 5$ & $107.67 \mathrm{~cd}$ \\
$\mathrm{a} 2 \mathrm{r} 0$ & $139.00 \mathrm{~b}$ \\
$\mathrm{a} 2 \mathrm{r} 1$ & $156.33 \mathrm{a}$ \\
$\mathrm{a} 2 \mathrm{r} 2$ & $145.33 \mathrm{a}$ \\
$\mathrm{a} 2 \mathrm{r} 3$ & $131.00 \mathrm{c}$ \\
$\mathrm{a} 2 \mathrm{r} 4$ & $138.33 \mathrm{~b}$ \\
\hline
\end{tabular}




\begin{tabular}{ll}
\hline$a 2 r 5$ & $141.00 \mathrm{~b}$ \\
$a 3 r 0$ & $130.67 \mathrm{c}$ \\
$\mathrm{a} 3 \mathrm{r} 1$ & $135.67 \mathrm{bc}$ \\
$\mathrm{a} 3 \mathrm{r} 2$ & $119.67 \mathrm{~cd}$ \\
$\mathrm{a} 3 \mathrm{r} 3$ & $126.67 \mathrm{c}$ \\
$\mathrm{a} 3 \mathrm{r} 4$ & $133.33 \mathrm{bc}$ \\
$\mathrm{a} 3 \mathrm{r} 5$ & $114.33 \mathrm{~cd}$ \\
$\mathrm{a} 4 \mathrm{r} 0$ & $119.67 \mathrm{~cd}$ \\
$\mathrm{a} 4 \mathrm{r} 1$ & $126.33 \mathrm{c}$ \\
$\mathrm{a} 4 \mathrm{r} 2$ & $137.67 \mathrm{~b}$ \\
$\mathrm{a} 4 \mathrm{r} 3$ & $130.00 \mathrm{c}$ \\
$\mathrm{a} 4 \mathrm{r} 4$ & $138.67 \mathrm{~b}$ \\
$\mathrm{a} 4 \mathrm{r} 5$ & $115.33 \mathrm{~cd}$ \\
$\mathrm{a} 5 \mathrm{r} 0$ & $89.00 \mathrm{~d}$ \\
$\mathrm{a} 5 \mathrm{r} 1$ & $87.67 \mathrm{~d}$ \\
$\mathrm{a} 5 \mathrm{r} 2$ & $81.67 \mathrm{~d}$ \\
$\mathrm{a} 5 \mathrm{r} 3$ & $82.33 \mathrm{~d}$ \\
$\mathrm{a} 5 \mathrm{r} 4$ & $85.00 \mathrm{~d}$ \\
$\mathrm{a} 5 \mathrm{r} 5$ & $82.33 \mathrm{~d}$
\end{tabular}

Note: The numbers followed by the same letters are not significantly different at the $5 \%$ level according to the Duncan test.

\section{CONCLUSION}

1. There were interactions on several quantitative parameters that were being tested i.e. the parameters of growing shoots, plant height, number of tillers, number of tillers out of segments, leaf length, and leaf width.

2. The fastest time for shoot to sprout was 12 days in the accession of Pulosari (a1) with a radiation dose of 0 (a1r0) and 30 Gray (a1r30).

3. The highest plant $(106.88 \mathrm{~cm})$ was found in the accession of Cikondang (a3) with a radiation dose of 20 Gray (a3r20) while the shortest is accession to Cikondang (a3) with a radiation dose of 40 Gray (A3R40).

4. The highest number of productive tillers (3.00) was found in the accession of Pulosari (a1) without radiation (a1r0) and the maximum number of out-of-section tillers (1.17) on the a2 (25 Pandeglang) accession and 40 Gray radiation (a2r40).

5. The largest effect of accession interactions and radiation doses on leaf length and width was found in the treatment (a3ro), which was $22.64 \mathrm{~cm}$ length and $10.17 \mathrm{~cm}$ width. While contrary, the smallest leaf size was obtained from the interaction between Cikondang (a3) accession and the radiation position of $40 \mathrm{~Gy}(\mathrm{r} 40)$.

6. The highest number of stomata was found in the treatment 25 Pandeglang (a2) accession with a radiation dose of 10 Gray (r10), which was 156.33 pieces.

\section{ACKNOWLEDGMENTS}

The author expresses her gratitude to the Ministry of Research, Technology and Higher Education of INSINAS 2019 event, for their funding of this study, as well as the Agronomy Laboratory for Evaluation of Biotechnology Products for their moral support in the completion of this research.

\section{REFERENCES}

Anggun, A., Supriyono, S., Syamsiyah, J. (2018). Pengaruh jarak tanam dan pupuk N, P, K 
terhadap pertumbuhan dan hasil garut (Maranta arundinacea L.). Agrotechnology Research Journal, 6(2), 33-38.

Arifin, M.S., A. Nugroho., A. Suryanto. (2014). Kajian Panjang Tunas Dan Bobot Umbi Bibit Terhadap Produksi Tanaman Kentang (Solanum Tuberosum L.) Varietas Granola. J. Produksi Tanaman, 2(3), 221-229.

Asha, K. I., Krishna Radhika, N., Vineetha, B., Asha Devi, A., Sheela, M. N., \& Sreekumar, J. (2015). Diversity analysis of arrowroot germplasm using ISSR markers. J. of Root Crops, 41.

Cahyuningdari, D.(2002).Pengaruh Ketersediaan Air Dan pemberian mulsa serbuk sabut kelapa pada pertumbuhan dan kandungan gula reduksi ubi jalar (Ipomoea batatas Lamk.). Skripsi. Jurusan Biologi. FMIPA. UNS. Surakarta.

Deswina, P., Indrayani, S., Perdani, A. Y., \& Mulyaningsih, E. S. (2019). Evaluation and Selection Fenotype of Garut Plant (Maranta arundinacea L.) with Gamma Ray Radiation Treatments. AGROSCRIPT Journal of Applied Agricultural Sciences, 1(1), 9-20.

Dewanti, M. (2004). Penampilan fenotipik dan parameter genetik anyelir (Dianthus caryophyllus Linn.) generasi MV3 hasil iradiasi sinar g!mma. Tesis. Program Pasca Sarjana Universitas Padjadjaran, Bandung

Direktorat Kacang-kacangan dan Umbi-umbian. (2002). Pengenalan budidaya talas, garut, ganyong, gembili, ubi kelapa, ilesiles, suweg/acung. Direktorat Jenderal Bina Produksi Tanaman Pangan. Jakarta

Djaafar, T.F. and S. Rahayu. (2006). Teknologi Pemanfaatan Umbi Garut, Pangan Sumber Karbohidrat. Badan Ketahanan Pangan bekerja sama dengan Pusat
Kajian Makanan Tradisional Universitas Gadjah Mada. Yogyakarta.

Djaafar, T.F., Sarjiman., A.B Pustika. (2010) Pengembangan budi daya tanaman garut dan teknologi pengolahannya untuk mendukung ketahanan pangan. J. Litbang Pertanian, 25 (1), 25-33

Faridah, D.N., D. Fardiaz., N. Andarwulan., T.C. Sunarti. (2014). Karakteristik sifat fisikokimia pati garut (Maranta arundinacea L.). J. Agritech, 34 (1), 1421.

Giono, B.R.W., M.F. Bdr., A. Nur., M.S Solle., I Idrus. (2014). Ketahanan genotype kedelai terhadap kekeringan dan kemasaman, hasil induksi mutasi dengan sinar gamma. J. Agroteknos, 4 (1), 44-52.

Glover, B. (2007). Understanding Flower and Flowering: An Integrated Approach. Oxford University Press. New York.

Gomez, K.A. \& Gomez, A. A. (1995). Prosedur Statistik Untuk Penelitian Pertanian. Penerbit Universitas Indonesia (UI Press). 698 pages.

Gurning, J.F., E.H Kardhinata., E.S Bayu.(2013). Evaluasi toleransi tanaman kedela (Glycine max L. Merrill) regeneran M4 hasil radiasi sinar gamma terhadap salinitas. J Agroekoteknologi,1 (2) 159 170. ISSN No. 2337- 659

Gusmaini, Sudiarto., H. Nurhayati. (2003). Pengaruh macam bahan tanaman terhadap pertumbuhan produksi umbiumbian dan pati garut. J. Ilmiah Pertanian IX ,(1), 13-21.

Hariyadi, P. (2010). Penguatan industri penghasil nilai tambah berbasis potensi lokal: Peranan teknologi pangan untuk kemandirian pangan. PANGAN. 19 No. 4 Desember 2010, 295-301. 
Hidayat, N., L.A.Sukamto., T.Juhaeti. (2012). Pengujian Ketahanan Kekeringan pada Tanaman Garut (Maranta arundinacea L.) Hasil Mutasi Dengan Radiasi Sinar Gamma. J. Bio. Indonesia 8(2),303-315.

Jan, S., T. Parween., T.O.Siddiqi. (2011). Gamma radiation effects on growth and yield attributes of Psoralea corylifolia L. with reference to enhanced production of psoralen. J. Plant Growth Regul, 64, 163171

Kaur, R., M. Kapoor.,R. Kaur.,A.Kumar. (2017). Effect of gamma irradiation on cytomorphology, total phenolic content and antioxidant activity of calendula. J of Hill Agriculture, 8 (4), 395-402.

Kusmiyati, M. (2013). Karakteristik Morfologi Garut (Marantha arundinacea L) Di Kabupaten Gunung Kidul Dan Kulon Progo D.I.Y. Skripsi Program Studi Biologi Fakultas SAINS dan Teknologi Universitas Islam Negeri Sunan Gunung Kalijaga Yogyakarta.

Lathifah, M. N., Supriyono, S., Mujiyo, M. (2017). Respon Garut Terhadap Jumlah Benih Dan Dosis Pupuk Organik. Caraka Tani: J. of Sustainable Agriculture, 32(2), 101-107.

Maghfoer, M.D., H. Djajasukanta, G.,Suryatmana., R.Setiamihardja. (2003). Respon pertumbuhan Tanaman Garut (Maranta arundinacea L.) Dengan Penaungan Terhadap pemupukan kalium. AGRIVITA, 25(3), 211-220.

Mutaqin, A,Z, R. Budiono, T. Setiawati, M. Nurzaman, R. S Fauzia. (2016). Studi anatomi stomata daun manga (Mangifera indica) berdasarkan perbedaan lingkungan. J. Biodjati ,1 (1), 13-18.
Oktafani, M. B., M.M Budiastuti., D. Purnomo. (2018). Performance of arrowroot (Marantha arundinacea L.) in various light intensities. In IOP Conference Series: Earth and Environmental Science,142 (1), 012048. IOP Publishing.

Rahman, M., Chowdhury, M., Uddin, A., Islam, M. T., Uddin, M. E., \&Sumi, C. D. (2015). Evaluation of antidiarrheal activity of methanolic extract of Maranta arundinacea Linn. leaves. J Advances in pharmacological sciences, 2015 (1), 1-6.

Ramadhani, M.R., Bachri, M.S. \& Widyaningsih, W. (2017). Effects of Ethanolic Extract of Arrowroot Tubers (Maranta arundinaceaL.) on the Level of MDA, SGPT and SGOT in Ethanol Induced Rats. Indonesian Journal of Medicine and Health, 8 (1), 10-18.

Sastra, D.R. (2003). Analisis keragaman genetik Marantha arundinacea L. berdasarkan penanda molekuler RAPD. J. Sains dan Teknologi Indonesia, 5(5), 209-218.

Sarjiman and T.F. Djaafar. (2007). Pemupukan garut pada lahan pekarangan untuk meningkatkan pendapatan masyarakat di lahan marginal. 183-189. Prosiding "Seminar Nasional Inovasi Teknologi dan Kelembagaan Pertanian dalam Upaya Peningkatan Pemberdayaan Masyarakat" Yogyakarta.

Shintu P.V., Radhakrishnan, V.V. \& Mohanan, K.V. (2016). A Study of the Genetic Variability of West Indian Arrowroot (Maranta arundinacea L.) in Kerala State of India. J. Agriculture Forestry and Fisheries, 5 (5), 186-190.

Soeranto, H. (2003). Peran iptek nuklir dalam pemuliaan untuk mendukung industri pertanian. 308-316. In. K. Abraham, Y. Arrianto, D.W. Nurhayati, Sujatmoko, R. Sukarsono, T.T. Basuki, A. Takazani, IGN 
J. Sarjono, T. Marjiatmono, Syarif, Sudianto, Samin, T. Tjiptono, dan D. Sujiko (eds.) Prosiding: Pertemuan dan Presentasi IImiah Penelitian Dasar IImu Pengetahuan dan Teknologi Nuklir 8 Juli 2003. P3TM Batan. Yogyakarta.

Suhartini, T.,and Hadiatmi. (2011). Keragaman Karakter Morfologis Garut (Maranta arundinaceae L.). Buletin Plasma Nutfah, 17(1), 12-18.

Yamaguchi, H., Shimizu, A., Degi, K., Morishita, T. (2008) Effects of dose and dose rate of gamma ray irradiation on mutation induction and nuclear DNA content in chrysanthemum. J. Breeding Science 58, 331-335.

Yuniastuti, E., S. Hartati, dan S.R.Widodo. (2012). Karakterisasi Morfologi Tanaman Durian Sukun (Durio zibenthinus Murr.). Prosiding. "Seminar Nasional Pendidikan Biologi" FKIP UNS.

Zanzibar, M and Witjaksono.(2011). Pengaruh Penuaan dan Iradiasi Benih dengan Sinar Gamma (60C) Terhadap Pertumbuhan Bibit Suren (Toona sureni Blume Merr). J. Penelitian Hutan Tanaman. 8 (2), 89-95. 